\title{
Maternal and paternal parenting styles as a whole: validation of the simple form of the Parenting Style Evaluation Scale
}

\author{
Álvaro Balaguer ${ }^{1}$, Edgar Benítez ${ }^{2 *}$, Jesús de la Fuente ${ }^{1}$, and Alfonso Osorio ${ }^{1,3}$ \\ 1 School of Education and Psychology, University of Navarra (Spain). \\ 2 Institute of Data Science and Artificial Intelligence (DATAI), University of Navarra (Spain). \\ 3 Institute for Culture and Society, University of Navarra (Spain).
}

\begin{abstract}
Título: Estilos parentales materno y paterno en conjunto: validación de la forma simple de la Escala de Evaluación del Estilo Parental

Resumen: La Escala para la Evaluación del Estilo Parental (EEEP) pregunta a los adolescentes sobre los estilos educativos de sus padres por separado ("tu padre" y "tu madre") o de forma conjunta ("tus padres"), pero solo se ha evaluado la validez en la versión por separado. El objetivo de este trabajo fue evaluar la validez de las inferencias de la versión conjunta. Se reclutó una muestra de 1507 adolescentes, de 12 a 18 años. Se realizaron análisis factoriales exploratorios y confirmatorios en dos submuestras independientes. Después se probó un modelo de ecuaciones estructurales para comprobar la asociación de las subescalas de la EEEP con desenlaces de los adolescentes (optimismo, pesimismo y resultados académicos). Los resultados muestran buenas medidas de ajuste de la estructura del instrumento. Además, las subescalas mostraron asociación con los desenlaces. La EEEP puede ser usada con fiabilidad en su forma conjunta, resultando en una reducción de ítems, los cual es a menudo beneficioso para la investigación.

Palabas clave: Validación. Estilos parentales. Modelo de ecuaciones estructurales. Adolescencia.
\end{abstract}

Abstract: Oliva's Escala para la Evaluación del Estilo Parental (EEEP) [Scale for the evaluation of parenting styles 7 asks adolescents about their parents' education styles separately ("your father" and "your mother") or in a combined way ("your parents"), but only the separated version has been tested for validity. The objective of this work was to carry out a validation of the combined version. A sample of 1507 adolescents, aged 12 to 18 years, was recruited. Exploratory and confirmatory factor analyses were run in two independent subsamples. Then, structural equation models (SEM) were run in order to test the association between the EEEP's subscales and adolescent outcomes (optimism, pessimism, and academic achievement). Results showed a good fit of the instruments' structure. Furthermore, the subscales showed associations with the outcomes. The EEEP can be reliably used in its combined form, which results in a reduction of items, often beneficial for research.

Keywords: Scale validation. Parenting styles. Structural equation modeling. Adolescence.

\section{Introduction}

Parents serve as role models for their children, who learn beliefs and behaviors from them (Álvarez et al., 2019; Varela et al., 2019). Relationships with parents are essential socioemotional (Collins \& Steinberg, 2006) and moral assets (Mounts \& Allen, 2019), even beyond childhood, and strongly influence child development. Accordingly, it is important to develop relevant assessment instruments to improve young people's development. In recent decades, there has increased interest in defining and measuring the dimensions of parenting style (Smetana, 2017).

\section{Conceptualizations of Parenting Styles}

The first investigations into parenting styles focused on samples of children (Baumrind, 1967; Maccoby \& Martin, 1983). However, in the 21st century, interest in parentadolescent relationships has increased. Obtaining information from children directly rather than their parents reduces social desirability bias and increases objectivity (Gonzales et al., 1996). The first studies in this area took a typological approach to categorizing parenting styles (Baumrind, 1967; Maccoby \& Martin, 1983). This approach classifies

* Correspondence address [Dirección para correspondencia]:

Edgar Benítez. Institute of Data Science and Artificial Intelligence (DATAI), University of Navarra. Campus Universitario 31009. Pamplona (España).E-mail: ebenitezs@unav.es

(Article received: 27-12-2019; revised: 14-04-2020; accepted: 20-08-2020) parenting styles in a generalized way, mainly in terms of the variables affection and control, which together compose the authoritative parenting style (Laursen \& Collins, 2009; Steinberg \& Silk, 2002). Later, the dimensional approach was developed to complement the typological approach (Steinberg \& Silk, 2002).

Studies subsequent to Baumrind indicated that the dimensions of control and affection were not completely independent, since parents' degree of affection influences the external manifestation of control (Darling \& Steinberg, 1993). There is abundant literature demonstrating the importance of parental warmth in adolescent adjustment, development, and social and emotional well-being (Collins \& Laursen, 2004). Establishing which indicators support control has been controversial. For example, some scales measuring control include parents' knowledge of their children's activities (Oliva et al., 2007). However, such knowledge may be the result either of parents' efforts or of children's selfdisclosure, which in turn becomes an important variable to measure (Laird \& Zeringue, 2019; Stattin \& Kerr, 2000).

Some authors distinguish behavioral control from psychological control, positioning the latter as clearly negative. "Psychological control" in this context refers to a parent's attempts to control their child's feelings, thoughts, or interests (Schaefer, 1965). More specifically, it involves parental manipulation of and intrusion into children's thoughts using methods such as constant criticism, guilt induction, or emotional blackmail (Mageau et al., 2015; Oliva et al., 2007). Behavioral control, in contrast, has been associated with better outcomes among adolescent children (Darling, 1999). 
However, some instruments do not distinguish between types of control, and results can differ depending on how control is measured (González-Cámara et al., 2019; Osorio \& González-Cámara, 2016). For example, some studies have included physical punishment (Fuentes et al., 2015) or exaggerated rule setting (Calafat et al., 2014) in their assessment of the control dimension. Such studies have found that control is associated with worse adolescent outcomes when defined in this way. Though some authors suggest that this is due to cultural differences, others attribute it to changes in recent decades (Garcia et al., 2019). A recent systematic review shows that the association between parental control and adolescent outcomes depends on how control is measured and that it is therefore important to distinguish between behavioral and psychological control (González-Cámara et al., 2019).

In addition, promotion of autonomy is closely related to authoritative parenting style (Oliva et al., 2007). While promotion of autonomy has sometimes been understood as a lack of psychological control, Barber et al. (2005) showed that these are different dimensions. In terms of its influence on child development, promotion of autonomy has been associated with better academic performance (DiaconuGherasim \& Măirean, 2016; Steinberg, 2001).

Finally, Oliva et al. (2007) included humor in their instrument for the evaluation of parenting style in order to evaluate the attitude of joy and optimism between parents and children. This attitude shapes a more positive climate that promotes the welfare of both parents and children, as well as positive parent-child relationships (Darling \& Steinberg, 1993; Oliva et al., 2007).

\section{Instruments Measuring Parenting Styles}

Some instruments that measure parenting styles are oriented towards infant children. Such instruments collect perceptions from both parents, such as the Parent-Child Relationship Inventory (Gerard, 1994) or from mothers only, such as the Escala de prácticas parentales prosociales (ZacaríasSalinas \& Andrade-Palos, 2014). Other instruments can be used for both infant and adolescent children, including the Alabama Parenting Questionnaire (Shelton et al., 1996), the Children's Reports of Parental Behavior Inventory (Schaefer, 1965), the Cuestionario sobre la calidad de las relaciones padres-bijos (Ortega \& Triana, 2002), the Parental Perceptions Questionnaire (Pasquali \& de Araújo, 1986), and the Parenting Style Inventory II (Darling \& Toyokawa, 1997). According to a recent systematic review (González-Cámara et al., 2019), the most frequently used instruments in the 21 st century to date have included the Parenting Styles Index (Steinberg et al., 1992), the Parental Socialization Scale (Musitu \& García, 2001), the Child's Report of Parental Behavior Inventory (Schaefer, 1965), the Parental Acceptance-Rejection/Control Questionnaire (Rohner \& Khaleque, 2005), and the Escala para la Evaluación del Estilo Parental [Scale for the Evaluation of Parenting Styles] (EEEP; Oliva et al., 2007).
According to the cited systematic review, the EEEP is one of the most used instruments in the Hispanic world. It encompasses a wide range of parenting dimensions and offers a reduced number of items but very acceptable reliability indices. Specifically, the EEEP measures six subscales: psychological control (PC), behavioral control (BC), affection and communication (AC), humor $(\mathrm{H})$, promotion of autonomy (PA), and self-disclosure (SD). While the EEEP can be used to evaluate maternal and paternal styles either separately ("your father" and "your mother") (Oliva et al., 2007) or together ("your parents") (Oliva et al., 2011), only the former has been validated. Given the increasing necessity of using short and simple instruments, validating the simple version of this instrument is of interest.

\section{Aims and Hypotheses}

This study aimed to validate the simple version of the EEEP for maternal and paternal parenting styles measured together. In a departure from previous work (Oliva et al., 2007), this research reassessed the reliability and validity of the scores of the EEEP among a diverse sample of adolescents. The study intended to replicate the original structure of the latent variables and find associations with external variables. Specifically, we expected:

- to replicate the same six-factor structure with good adjustment indices;

- to find good internal consistency indices for each factor;

- to find associations between psychological control and worse outcome variables (inverse association with academic performance and optimism, direct association with pessimism); and

- to find associations between the other EEEP factors and better outcome variables (direct association with academic performance and optimism, inverse association with pessimism).

\section{Methods}

\section{Participants}

The inclusion criteria for data collection were targeted towards schools offering curricular programs to adolescents in the province of Zaragoza, Spain. In Spain, these programs comprise the educational stages of compulsory secondary education, baccalaureate, initial professional qualification programs, and professional training. Ten schools were randomly selected from all secondary schools in the province of Zaragoza, with a proportional representation of public vs. private and urban vs. rural schools: seven public schools (four urban, three rural) and three private urban schools. Of these, seven schools agreed to participate: six public schools (four urban, two rural) and one private urban school. At these schools, we requested participation from students in 
grades 7,9 , and 11 (approximately 12, 14, and 16 years old, respectively).

The sample consisted of 1,507 adolescents (49.5\% girls). Among participants, 33.2\% were 11-13 years old, 32.8\% were $14-15$ years old, and $34.0 \%$ were over 15 years old. Roughly half of participants $(50.8 \%)$ were from public urban schools, while $39.0 \%$ attended public rural schools and $10.2 \%$ attended a private urban school.

\section{Instruments}

EEEP (Oliva et al., 2007). This instrument evaluates several dimensions of parents' style based on the perceptions of their adolescent children (at least 12 years old). The version we used does not differentiate between paternal and maternal parenting styles but asks about parents' jointly. It consists of 41 items, and is divided into six factors: psychological control (8 items); behavioral control (6 items); affection and communication (8 items); humor (6 items); promotion of autonomy ( 8 items); and self-disclosure (5 items). The items are scored on a Likert scale $(1=$ strongly disagree to $6=$ totally agree). In the authors' validation, the reliability indices (Cronbach's alpha) of the subscales were as follows for mothers and fathers, respectively: psychological control (.80 and .80); behavioral control (.76 and .78); affection and communication (.88 and .90); humor (.82 and .82); promotion of autonomy (.83 and .83); and self-disclosure (.83 and .85).

Youth Life Orientation Test (Ey et al., 2005). This measure is adapted from the revised Life Orientation Test (Scheier et al., 1994) to assess optimism in children and adolescents between 7 and 18 years old. It consists of two subscales, optimism and pessimism, which can be measured either jointly and separately. In total, the measure contains 14 items: 6 optimistic items, 6 pessimistic items, and 2 distracting items. In the Spanish version adapted by Royo (2016), statements are scored on a Likert scale $(1=I$ never think that way to $5=I$ always think that way). The internal consistency of the two scales for the Spanish version of the instrument was .62 for optimism and .78 for pessimism.

Academic performance. Participants were asked the average grade of their academic record for the previous year.

\section{Procedure}

The objectives and characteristics of the study were explained to the principals and counselors at each school. Prior to participation in the study, families were informed via letter about the purpose and procedure of the study. Participants' anonymity was ensured, and schools were informed that they should exclude children whose families did not want them to participate.

The questionnaires were completed during school hours. The teacher of each classroom read the instructions to the students and supervised them during completion. Questionnaires were completed over the course of 1 hour. After completing the study, each school received an individualized report with the overall results of their students.

The Ethical Guidelines for Educational Research were followed (British Educational Research Association, 2011). No compensation was granted for participating in the study. Ethical approval was obtained for the project from the Academic Commission of the University of Zaragoza, Spain.

\section{Data Analysis}

The analysis began with a general evaluation of evidence of reliability and validity. We evaluated the internal reliability of each construct before proceeding to the validation of inferences of the scale (Muñiz \& Fonseca-Pedrero, 2019), using independent samples for exploration through exploratory factor analysis (EFA) and confirmatory factor analysis (CFA). Questionnaires that were not completed were discarded from the analyses.

For the full sample, adjustment statistics were estimated to the normal distribution and skewness and kurtosis were calculated. The adjustment was rejected, and we needed to estimate the polychoric correlation matrix as an alternative to the Pearson matrix for subsequent analyses (Ferrando \& Lorenzo-Seva, 2014; Lloret-Segura et al., 2014). The internal evidence of the reliability of the instrument's scores was estimated using the ordinal coefficient alpha (OCA; Contreras \& Novoa-Muñoz, 2018; Zumbo et al., 2007) and compared with the omega coefficient (Dunn et al., 2014).

Parallel analysis was used to define the number of factors (Glorfeld, 1995). EFA was then performed on the polychoric matrix of correlations within a random half of the sample using the unweighted least squares method. Loads above 0.4 units were considered significant (Lloret-Segura et al., 2014). This EFA was compared with that performed on the Pearson correlation matrix estimated by maximum likelihood. Promax was the factor rotation used for both cases, from which the correlations between factors were estimated. We evaluated two alternatives for the remaining sample using CFA. The first was based on the authors' proposal (Oliva et al., 2007) and incorporated six independent dimensions, and the second used three dimensions: Behavioral Control, Psychological Control, and Positive Parenting (Affection and Communication, Humor, Promotion of Autonomy, and Self-Disclosure), based on a classification of the dimensions made by the same authors (Oliva et al., 2011).

Robust two-stage maximum likelihood (RML; LloretSegura et al., 2014) was used for estimation purposes. The cutoff values proposed by $\mathrm{Hu}$ and Bentler (1999) for model validation were used: 1) comparative fit index $(\mathrm{CFI})>0.95$ and standardized root mean square residual (SRMR) $<0.09$; or 2) root mean square error of approximation (RMSEA) $<$ 0.05 and SRMR $<0.06$. The measurement properties of the instrument were estimated using the model chosen based on this analysis. Items were discarded due to low performance on the basis of item reliability $<0.4$, composite reliability $<$ 0.7 , variance extracted $<0.5$ units, and convergent validity $t$ 
value $>1.96$ (Fornell \& Larcker, 1981; O’Rourke \& Hatcher, 2013).

Likewise, the modification indices of the Ward test and the Lagrange multiplier were used to restrict or release parameters, respectively. Suggestions were accepted if they presented explainable changes related to the conceptual theory of the model and if the variations in $\chi^{2}$ values were significant at $p<.05$. Modifications to the model were made individually. Data analysis was performed using SAS version 9.4 (SAS, 2020).
Once the instruments were validated, we proceeded to identify evidence of external validation through a two-step structural equation modeling (SEM) approach (Anderson \& Gerbing, 1988; O’Rourke \& Hatcher, 2013). Parenting Style was evaluated in terms of its six constructs (Psychological Control, Behavioral Control, Affection and Communication, Humor, Promotion of Autonomy, and Self-Disclosure) as predictors of adolescents' Dispositional Optimism and Academic Performance. The resulting model was evaluated for invariance (mean and covariance) by multigroup analysis by sex (Figure 1).

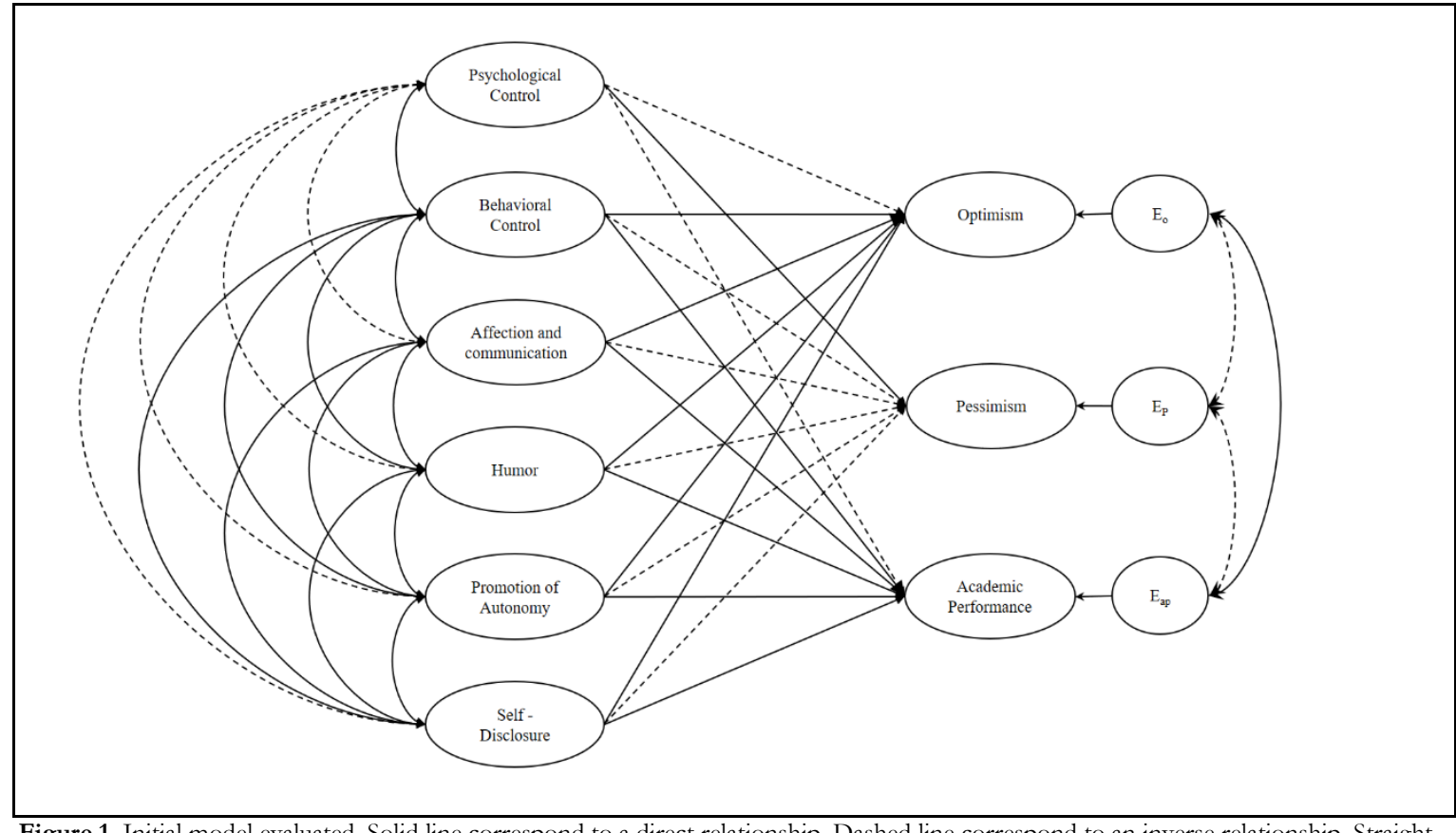

Figure 1. Initial model evaluated. Solid line correspond to a direct relationship. Dashed line correspond to an inverse relationship. Straight lines are unidirectional relationship. Curve arrows correspond to covariance relationship.

\section{Results}

\section{Exploratory Factor Analysis}

Prior to EFA and CFA, normality inspection was performed by calculating skewness and kurtosis for each item of the instrument (Table 1). Skewness was high for almost all variables, and kurtosis was high for some variables in the $A$ fection and Communication construct. As a consequence of this condition, we risked underestimating both the internal con- sistency of the instrument's constructs and the factorial loads if the Pearson product-moment correlation matrix was used (Ferrando \& Lorenzo-Seva, 2014). Therefore, calculations were performed in parallel on half of the sample, taken at random for the training analysis of the model, which consisted of the internal consistency indices and factor loads of the EFA both on the Pearson product-moment matrix and on the polychoric matrix (Table 1). Parallel analysis confirm the six dimensions structure of the original model (Figure 2).

Table 1. Statistics for the variables and constructs of parenting styles, normal adjustment, internal consistence, and Exploratory Factor Analysis.

\begin{tabular}{|c|c|c|c|c|c|c|c|c|}
\hline \multirow[t]{2}{*}{ Construct } & \multirow[t]{2}{*}{ Item } & \multirow[t]{2}{*}{$\begin{array}{l}\text { Omega } \\
\text { coefficient }\end{array}$} & \multirow[t]{2}{*}{ Skewness } & \multirow[t]{2}{*}{ Kurtosis } & \multirow[t]{2}{*}{$\begin{array}{l}\text { Ordinal } \\
\text { Alpha }\end{array}$} & $\begin{array}{c}\text { Factorial loads based on } \\
\text { polychoric matrix correlation }\end{array}$ & \multirow{2}{*}{$\begin{array}{l}\text { Cronbach } \\
\text { alpha }\end{array}$} & \multirow{2}{*}{$\begin{array}{l}\text { Factorial loads based on } \\
\text { Pearson matrix correlation } \\
\text { PC BC AC H PA SD }\end{array}$} \\
\hline & & & & & & $\begin{array}{llllll} & \text { PC } & \text { BC } & \text { AC } & \text { PA } & \text { SD }\end{array}$ & & \\
\hline Psychological & & .86 & & & .88 & & .85 & \\
\hline Control (PC) & 15 & & 0.04 & -0.13 & & $.50^{*}$ & & $.47^{*}$ \\
\hline & 16 & & 0.45 & -0.11 & & $.75^{*}$ & & $.71 *$ \\
\hline & 17 & & 0.31 & -0.01 & & $.78^{*}$ & & $.76^{*}$ \\
\hline & 18 & & -0.01 & -0.11 & & $.57 *$ & & $.57 *$ \\
\hline & 19 & & -0.19 & -0.11 & & $.67 *$ & & $.64^{*}$ \\
\hline
\end{tabular}




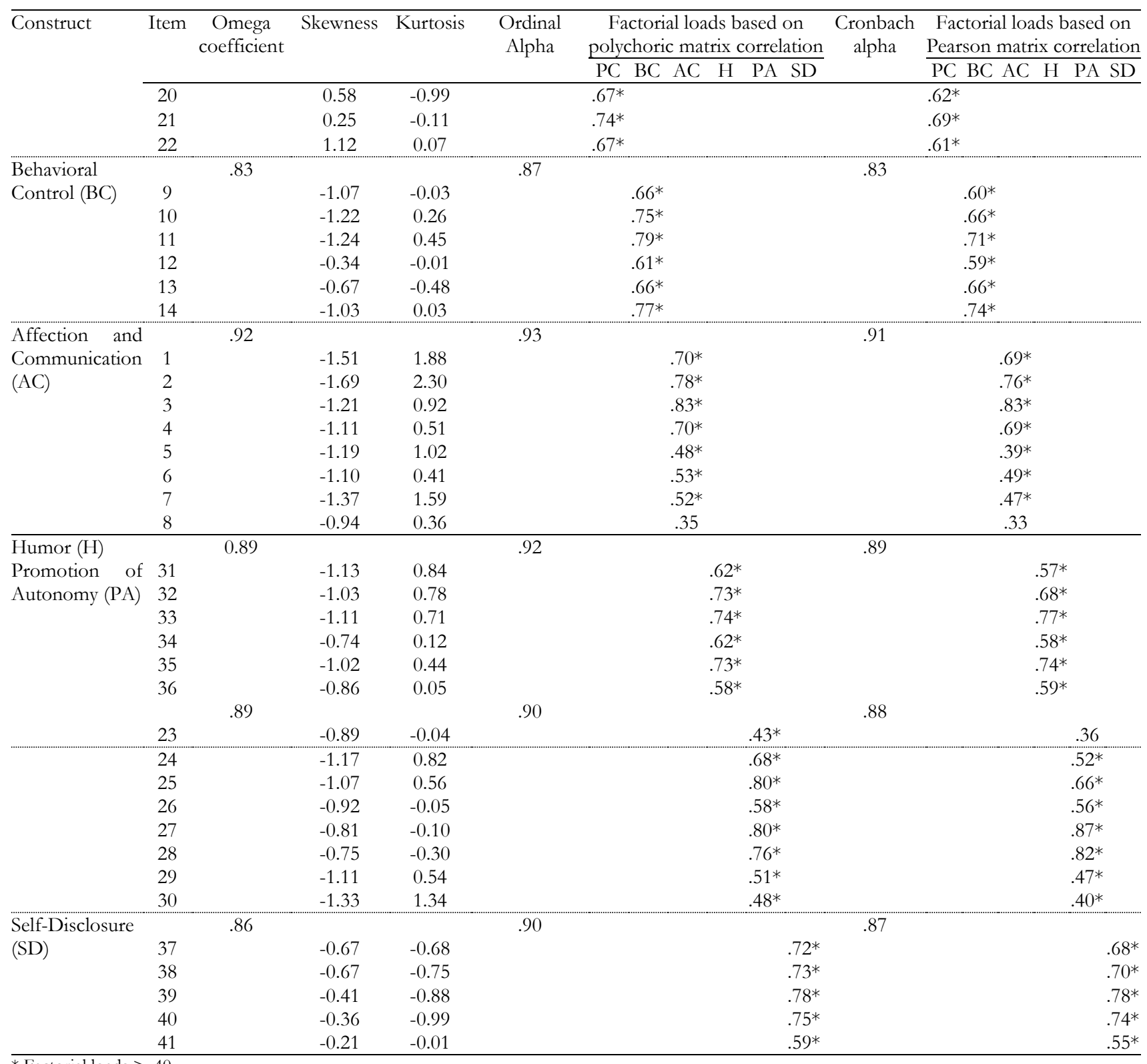

Normality adjustment statistics (skewness and kurtosis), internal reliability coefficients for each dimension (Cronbach alpha and Ordinal Alpha), and factor loads estimated from the polychoric correlation matrix and Pearson product-moment, for the items that are part of the instrument that evaluates Parenting Styles.

We found high OCA values for the Affection and Communication, Promotion of Autonomy, Humor, and Self-Disclosure constructs $(\alpha \geq 0.9)$, which suggested possible multicollinearity. For the EFA, although the underestimation effect of the Pearson matrix was generally observed, both results (that generated from the Pearson matrix and that generated from the polychoric matrix) presented the same structure, with the items loading on their respective dimensions. Omega coefficient values were similar to Cronbach's alpha values. The model also revealed some strong correlations between constructs, with the exception of Psychological Control and Behavioral Control (Table 2).
Table 2. Matrix of correlation between constructs of Parenting Styles.

\begin{tabular}{lcccccc}
\hline \multicolumn{1}{c}{ PC } & BC & AC & H & PA & SD \\
\hline PC & 1.00 & & & & & \\
BC & .23 & 1.00 & & & & \\
AC & -.35 & .34 & 1.00 & & & \\
H & -.34 & .27 & $.67^{*}$ & 1.00 & & \\
PA & -.25 & .27 & $.58^{*}$ & $.56^{*}$ & 1.00 & \\
SD & -.16 & .35 & $.53^{*}$ & $.49^{*}$ & $.53^{*}$ & 1.00 \\
\hline * Correlation
\end{tabular}

* Correlation coefficient $>.40$

Matrix of correlation between the scores of the factors: Psychological Control (PC), Behavioral Control (BC), Affection and Communication (AC), Humor (H), Promotion of Autonomy (PA), and Self-disclosure (SD). 


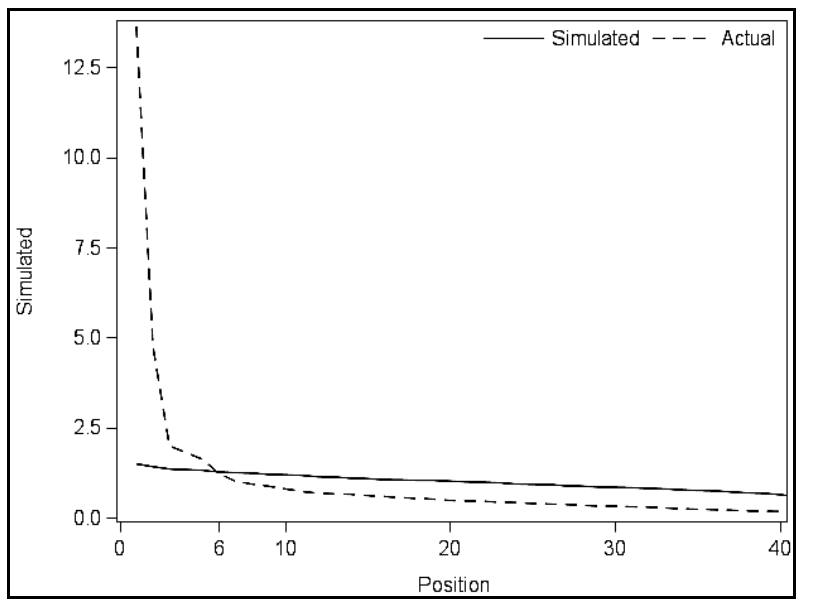

Figure 2. Parallel Analysis (PA) for the definition of the number of dimensions in which the generated data are grouped for the model of Parenting Style (PS). The intersection between the simulated data and the actual data indicates the number of factors to be retained in the exploratory factor analysis (EFA).

Table 3. Properties of the measurement instrument.

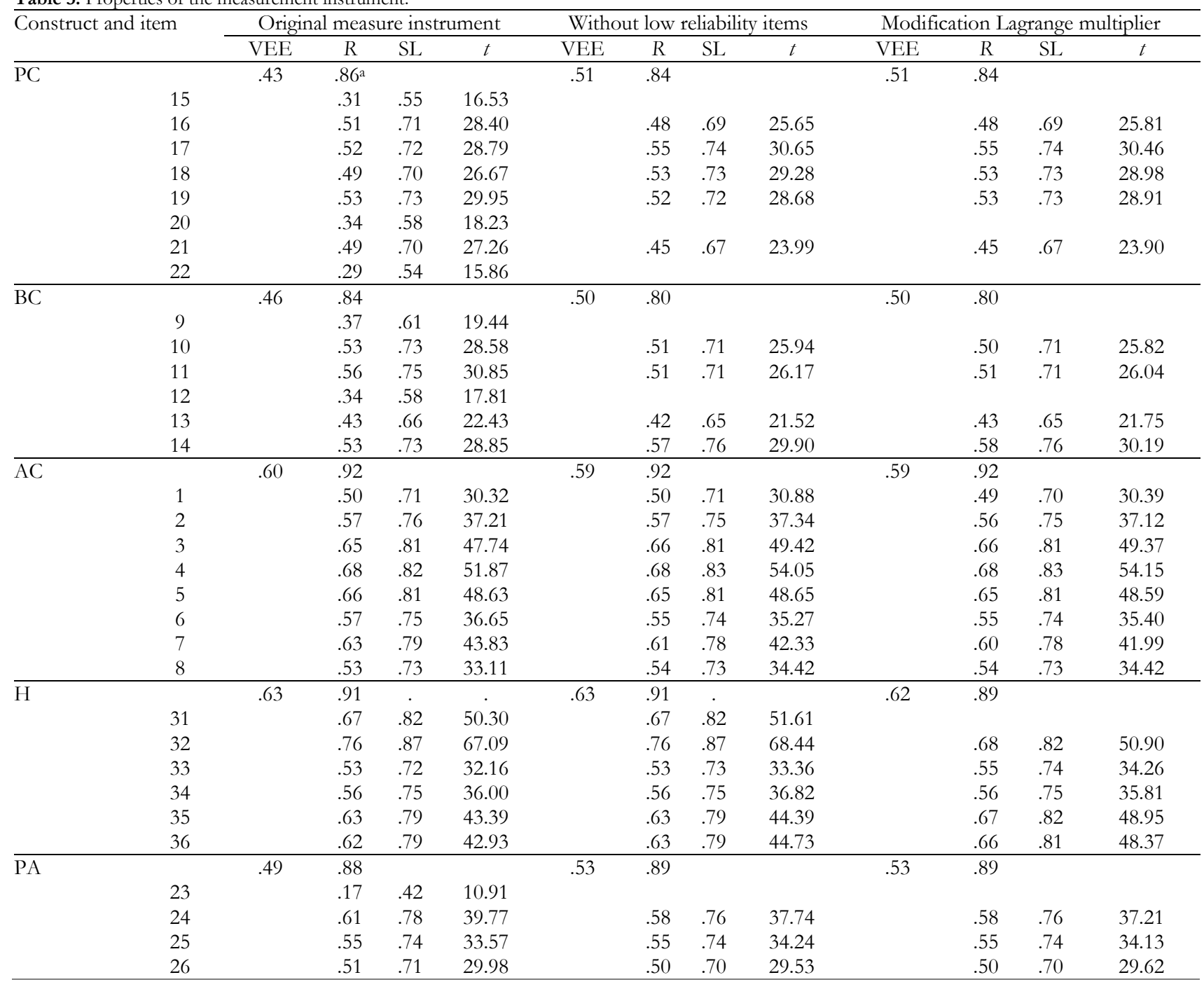

Up to this point, the multicollinearity (high OCA) and divergent validity (correlations between factors) of the instrument showed low adjustment of the model. To improve this adjustment, we identified the poorly performing constructs and their respective items and proceeded to eliminate them. Items 9 and 12 of Behavioral Control; items 15, 20, and 22 of Psychological Control; and item 23 of Promotion of Autonomy were removed from the instrument in this way (Table 3). 


\begin{tabular}{|c|c|c|c|c|c|c|c|c|c|c|c|c|}
\hline \multirow[t]{2}{*}{ Construct and item } & \multicolumn{4}{|c|}{ Original measure instrument } & \multicolumn{4}{|c|}{ Without low reliability items } & \multicolumn{4}{|c|}{ Modification Lagrange multiplier } \\
\hline & VEE & $R$ & $\mathrm{SL}$ & $t$ & VEE & $\mathrm{R}$ & SL & $t$ & VEE & $R$ & SL & $t$ \\
\hline 27 & & .57 & .75 & 35.12 & & .56 & .75 & 35.60 & & .57 & .75 & 35.88 \\
\hline 28 & & .59 & .77 & 37.94 & & .59 & .77 & 38.02 & & .58 & .76 & 37.73 \\
\hline 29 & & .52 & .72 & 30.54 & & .52 & .72 & 31.14 & & .52 & .72 & 31.22 \\
\hline 30 & & .41 & .64 & 22.93 & & .41 & .64 & 23.41 & & .41 & .64 & 23.18 \\
\hline$\overline{\mathrm{SD}}$ & .61 & .89 & & & .60 & .88 & & & .62 & .87 & & \\
\hline 37 & & .55 & .74 & 33.14 & & .54 & .74 & 33.51 & & & & \\
\hline 38 & & .57 & .75 & 35.12 & & .57 & .75 & 35.77 & & .50 & .71 & 29.39 \\
\hline 39 & & .74 & .86 & 57.28 & & .73 & .86 & 57.62 & & .77 & .88 & 61.74 \\
\hline 40 & & .70 & .83 & 50.59 & & .68 & .83 & 50.04 & & .73 & .86 & 55.63 \\
\hline 41 & & .51 & .71 & 29.79 & & .49 & .70 & 29.15 & & .49 & .70 & 29.04 \\
\hline
\end{tabular}

R: Reliability; VEE: Variance Extraction Estimates; SL: Standardized load; t: t value.

a Composite Reliability.

Properties of the instruments for measuring Parenting Styles in the validation process. Original instrument, instrument without items of low reliability, and instrument modified by the indices produced by the Lagrange Multiplier.

\section{Confirmatory Factor Analysis}

Our CFA began by evaluating the two proposed theoretical alternatives: the six-dimensional model proposed by Oliva, and the model reduced to three dimensions: positive parenting (Affection and Communication, Humor, Promotion of $A u$ tonomy, and Self Disclosure) and two types of control. In our analysis, the original model proposed by the authors performed better than the alternative where the variables related to positive parenting were grouped (CFI: 0.89, 0.77; TuckerLewis index [TLI]: 0.88, 0.76; SRMR: 0.057, 0.075; RMSEA: $0.059,0.086,90 \%$ CI $[0.056,0.059]$ and $[0.083,0.088]$, respectively).
The three-dimensional model was discarded, and the original model was evaluated against the model from which items with low reliability were removed. The modification indices of the Ward test and the Lagrange multiplier were then applied, one modification at a time (Table 4). For this method, the ideal adjustment criteria and improvements to the model that would not affect the content validity criteria or the stability of the factor estimate were addressed. Based on this analysis, two items were removed (31 of Humor and 37 of Self-disclosure) for which the Lagrange multiplier identified a relationship between items of the same construct (multicollinearity).

Table 4. Goodness-of-Fit Indices for Various Models, Parenting Styles $(\mathrm{N}=559)$.

\begin{tabular}{lccccccccc}
\hline Model & d. f. & $\chi 2$ & $\Delta$ d. f. & $\Delta \chi^{2}$ & TLI & CFI & SRMR & RMSEA & (RMSEA CL90) \\
\hline Base model & 820 & 13409.3 & & & & & & \\
Six factors model & 764 & 2160.8 & 56 & $11248.5^{* *}$ & 0.88 & 0.89 & 0.057 & 0.059 & $(0.056-0.059)$ \\
Without low reliability items & 545 & 1484.4 & 219 & $676.4^{* *}$ & 0.91 & 0.92 & 0.047 & 0.056 & $(0.052-0.059)$ \\
Without 31 & 512 & 1334.2 & 252 & $826.6^{* *}$ & 0.92 & 0.93 & 0.046 & 0.054 & $(0.050-0.057)$ \\
Without 37 & 480 & 1197.6 & 65 & $286.8^{* *}$ & 0.93 & 0.93 & 0.048 & 0.052 & $(0.048-0.055)$ \\
\hline
\end{tabular}

$\chi^{2}=$ chi-square; d. f. = degrees of freedom; TLI: Tucker-Lewis Index; CFI = Comparative Fit Index; SRMR = Standardized Root Mean Square Residual; RMSEA $=$ Root Mean Square Error of Approximation; RMSEA $(90 \% \mathrm{CI})=$ RMSEA $90 \%$ Confidence Limits. Each $\Delta$ was calculated from the previous model. $* * p<.01$

\section{Relationship between the Instrument, Dispositional Optimism, and Academic Performance through SEM}

The selected model's relationship with the external variables Dispositional Optimism and Academic Performance was evaluated via confirmatory analysis. Descriptive statistics for these subscales are presented in Table 5. The adjustment of Dispositional Optimism was first assessed through CFA, which showed optimal values of adjustment $(\mathrm{CFI}=.95$; TLI = .94; SRMR $=.0394 ;$ RMSEA $=.0542,90 \%$ CI [.048, .061]; $\alpha=$ .70 [optimism]; $\alpha=.80$ [pessimism]).
Table 5. Descriptive statistic for subscales used in the SEM model

\begin{tabular}{lllllll}
\hline Variable & Mean & $S D$ & Skewness & Kurtosis & $\begin{array}{c}\text { Cronbach Omega } \\
\text { alpha }\end{array}$ & coefficient \\
\hline OP_4 & 3.43 & 1.12 & -0.31 & -0.53 & 0.70 & 0.70 \\
OP_6 & 3.18 & 1.09 & -0.07 & -0.51 & & \\
OP_8 & 4.30 & 0.90 & -1.32 & 1.44 & & \\
OP_10 & 4.16 & 0.89 & -0.95 & 0.69 & & \\
OP_12 & 3.58 & 1.09 & -0.44 & -0.47 & & \\
OP_14 & 4.28 & 0.89 & -1.20 & 1.11 & & \\
PE_3 & 2.45 & 0.93 & 0.46 & 0.13 & 0.80 & 0.80 \\
PE_5 & 2.34 & 1.13 & 0.53 & -0.51 & & \\
PE_7 & 2.46 & 1.09 & 0.41 & -0.34 & & \\
PE_9 & 2.43 & 1.25 & 0.57 & -0.66 & & \\
PE_11 & 1.94 & 1.04 & 1.11 & 0.73 & & \\
PE_13 & 1.89 & 1.00 & 1.17 & 1.02 & & \\
AP & 4.30 & 2.27 & -0.17 & -1.13 & & \\
OP: dispositional optimism; PE: dispositional pessimism; AP: academic per-
\end{tabular}
formance. 
Once all measurement instruments were validated, the causal model was estimated using SEM. A correlation matrix for the scores of the factors evaluated is presented in Table 6. The Ward test modification indicator and convergent validity tests showed that some functional relationships were not significant $(p \geq .05)$. Such items were eliminated from the model. Although the elimination of non-significant relationships did not improve the indices of adjustment of the model, they were nevertheless removed in the search for a parsimonious model and a model not affected by relationships attributable only to chance (CFI $=.93$; TLI $=.92$; SRMR $=.040 ;$ RMSEA $=.042,90 \%$ CI $[.040, .044])$. The model presented in Figure 3 was obtained through this process.
Table 6. Matrix of correlation between constructs of SEM for external validation of Parenting Styles ( $\mathrm{N}=1075)$.

\begin{tabular}{llllllllll}
\hline & PC & BC & AC & H & PA & SD & OP & PE & AP \\
\hline PC & 1.00 & & & & & & & & \\
BC & .27 & 1.00 & & & & & & & \\
AC & -.39 & .31 & 1.00 & & & & & & \\
H & -.39 & .28 & .85 & 1.00 & & & & & \\
PA & -.42 & .31 & .81 & .79 & 1.00 & & & & \\
SD & -.21 & .53 & .67 & .66 & .61 & 1.00 & & & \\
OP & -.17 & .18 & .53 & .55 & .50 & .44 & 1.00 & & \\
PE & .35 & -.11 & -.45 & -.41 & -.40 & -.31 & -.83 & 1.00 & \\
AP & -.12 & .06 & .16 & .12 & .12 & .09 & .14 & -.20 & 1.00 \\
\hline
\end{tabular}

Matrix of Pearson correlation between the scores of the factors associated with Psychological Control (PC), Behavioral Control (BC), Affection and Communication (AC), Humor (H), Promotion of Autonomy (PA), and Self-disclosure (SD). Optimism (OP), Pessimism (PE), and Academic Performance (AP).

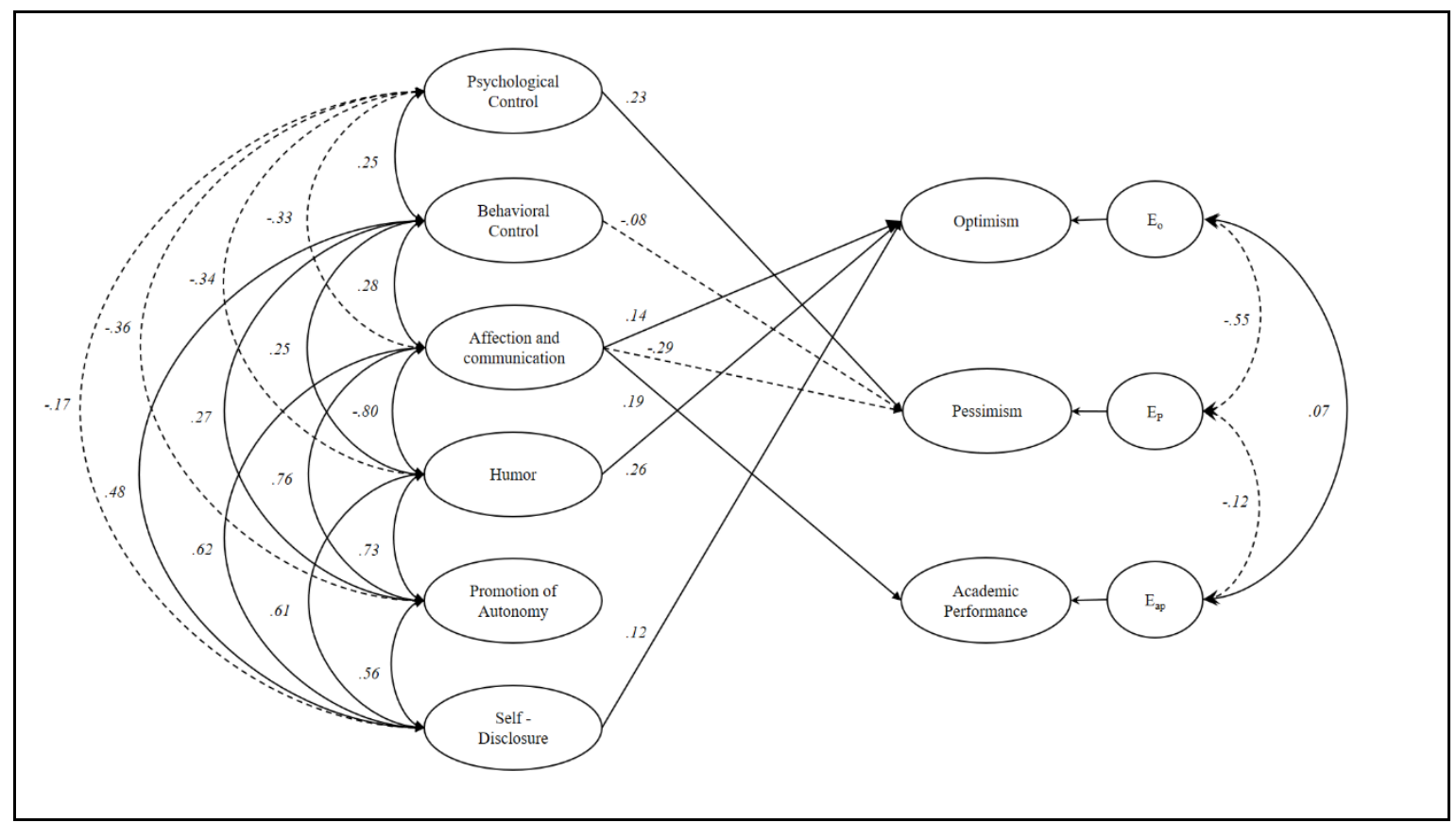

Figure 3. Estimated final model for the relationship between the constructs of Parental Style, Academic Performance, and Dispositional Optimism. The values represent the significant standardized linear coefficients $(p<0.05)$. Solid line correspond to a direct relationship. Dashed line correspond to an inverse relationship. Straight lines are unidirectional relationship. Curve arrows correspond to covariance relationship.

The resulting model shows that Pessimism was inversely influenced by Affection and Communication and Behavioral Control, and directly influenced by Psychological Control. On the other hand, Affection and Communication, Humor, and SelfDisclosure directly influenced Optimism. Finally, Academic Performance was directly influenced by Affection and Communication (Figure 3).

Finally, when evaluating the invariance of the model and considering boys and girls as groups, no changes were observed that indicated an improvement in the model (CFI = .92 ; SRMR $=.048$; RMSEA $=.045)$. However, when estimating the parameters for each sex, we found that, for boys, Affection and Communication no longer influenced Optimism ( $\hat{\beta}$ $=0.076 ; p=.45)$. In addition, the relationship between Optimism and Academic Performance was not present among boys ( $\hat{\rho}$
$=0.24 ; p=.63)$. On the contrary, for girls, Self-Disclosure was not significantly related to Optimism $(\hat{\beta}=.088 ; p=.10)$, and the negative effect of Behavioral Control on Pessimism disappeared $(\hat{\beta}=-.023 ; p=.62)$. For the remaining variables, the changes identified were on the level of magnitude, where $A f$ fection and Communication influenced girls over Pessimism at a rate almost double that among boys $\left(\hat{\beta}_{\text {boys }}=-.183 ; \hat{\beta}_{\text {girls }}=\right.$ -.364). This finding stands in contrast to Psychological Control and its influence on Pessimism, which in boys is almost double the rate estimated for girls $\left(\hat{\beta}_{\text {boys }}=.335 ; \hat{\beta}_{\text {girls }}=.151\right)$.

\section{Discussion}

The proposed model for evaluating parenting styles as a whole (i.e., for fathers and mothers jointly) encountered sev- 
eral difficulties not reported in previous studies (Oliva et al., $2007,2011)$. Overall, these difficulties were related to the biased behavior of some dimensions and the model's low reliability in the two dimensions related to parental control. This affected the performance of the model when assessed via CFA. Bias, which resulted in multicollinearity problems, was resolved with the use of adequate statistical techniques.

It was necessary to eliminate some items due to low reliability. In analyzing the content of these items, we observed that they were associated with extreme perceptions of their respective dimension. For example, in the psychological control dimension, questions associated with unexplained punishments or with parents who withdraw communication were removed. Similarly, in the behavioral control dimension, items related to exhaustive control of time and money were eliminated. Since these problems were not reported in the validation of the version of the instrument that evaluated maternal and paternal parenting styles separately (Oliva et al., 2007), we speculate that they might be related to mixing the responses of both parents. In other words, a parent's sex might be associated with differences in behavior that are not reflected in adolescents' ratings.

For dispositional optimism, although optimism and pessimism were expected to behave similarly (Hinz et al., 2017), differential effects were found. Pessimism was influenced by parental affection and communication, as well as both psychological and behavioral control. The two classical components of authoritative parenting (affection and communication and behavioral control) seemed to decrease pessimism, while psychological control seemed to increase it. This is consistent with the hypotheses of the present study. Affection and communication, together with self-disclosure and especially humor, were again shown to be precursors of optimism and positive factors in adolescent development. As these variables are usually considered components of positive parenting (Oliva et al., 2011), we expected that they would increase optimism (Hasan \& Power, 2002).

Although some authors consider pessimism to be a mirror image of optimism (Gustems-Carnicer et al., 2017), our findings did not support this view, as the predictive capacity of pessimism was greater than that of optimism. This effect has also been detected by other authors (Ey et al., 2005). An explanation for this differential effect can be found in the concept of cognitive dissonance within the construct of unrealistic optimism proposed by Kapikiran and AcunKapikiran (2016). According to these authors, when young people are asked about their optimistic vision of their lives, they tend to hide situations that diminish this perception. However, when adolescents are asked specifically about neg-

\section{References}

Álvarez, O., Castillo, I., \& Moreno-Pellicer, R. (2019). Transformational Parenting Style, Autonomy Support, and their Implications for Adolescent Athletes' Burnout. Psychosocial Intervention, 28(2), 91-100. https://doi.org/10.5093/pi2019a7 ative aspects (i.e., the pessimistic dimension), cognitive dissonance decreases, and pessimism becomes an important predictive factor that reveals the truth behind an adolescent's optimistic view of their life.

In line with previous literature, we expected that academic performance would be positively associated with behavioral control (Darling, 1999; González-Cámara et al., 2019; Waterman \& Lefkowitz, 2017). However, our initial model found only a small and non-significant association, which was dropped in the final model. The only variable that showed a significant effect on academic performance was affection and communication, which is consistent with other studies where this factor was found highly relevant (Pinquart, 2016).

\section{Limitations and Future Research}

We conclude by mentioning some of the limitations of our research. First, only children's perceptions were used in this study. This implies a bias that could increase the size of the relationship between the different variables analyzed. Second, social desirability and infrequency of response scales were not used to detect invalid or random response patterns. That said, as previously noted, this is a more reliable method of assessing parenting styles than using parents' perceptions, since relying on adolescents' points of view reduces social desirability bias and increases objectivity (Gonzales et al., 1996). Finally, we did not analyze factor invariance for different types of families or for different groups of adolescents. Such differences may be relevant in researching the effects of different parenting styles in society (Pearce et al., 2018). Future studies might consider this issue.

\section{Conclusion}

The tested model showed good fit indices and high internal reliability when asking adolescents about their parents' collective parenting style. In relation to the original version of the scale, it was possible to reproduce the six dimensions proposed by Oliva. However, some of the original items were removed because they reduced the reliability of the dimensions evaluated. The associations between parenting dimensions and adolescent outcomes were as expected, with the dimension of affection and communication best explaining adolescent outcomes, whether affective (optimism and pessimism) or behavioral (academic performance). The modified instrument can be used with sufficient assurance of quality.

Anderson, J. C., \& Gerbing, D. W. (1988). Structural Equation Modeling in Practice: A Review and Recommended Two-Step Approach. Psychological Bulletin, 103(3), 411-423. https://doi.org/10.1037/00332909.103.3.411 
Barber, B. K., Stolz, H. E., \& Olsen, J. A. (2005). Parental support, psychological control, and behavioral control: Assessing relevance across time, method, and culture. Monographs of the Society for Research in Child Development, 70(4), 1-137.

Baumrind, D. (1967). Child care practices anteceding three patterns of preschool behavior. Genetic Psychology Monographs. US: Heldref Publications.

British Educational Research Association. (2011). Ethical Guidelines for Educational Research. Retrieved from https://www.bera.ac.uk/publication/ethical-guidelines-for-educationalresearch-2011

Calafat, A., García, F., Juan, M., Becoña, E., \& Fernández-Hermida, J. R. (2014). Which parenting style is more protective against adolescent substance use? Evidence within the European context. Drug and Alcohol Dependence, $138(1)$,

185-192. https://doi.org/10.1016/j.drugalcdep.2014.02.705

Collins, W. A., \& Laursen, B. (2004). Parent-adolescent relationships and influences. In R. M. Lerner \& L. Steinberg (Eds.), Handbook of adolescent psychology (Vol. 2, pp. 331-362). New York, NY: Wiley Online Library.

Collins, W. A., \& Steinberg, L. (2006). Adolescent Development in Interpersonal Context. In W. Damon \& R. M. Lerner (Eds.), Handbook of child psychology: Social, emotional, and personality development, Vol. 3. (6th ed., pp. 1003-1067). Hoboken, NJ, US: John Wiley \& Sons Inc.

Contreras, S., \& Novoa-Muñoz, F. (2018). Ventajas del alfa ordinal respecto al alfa de Cronbach ilustradas con la encuesta AUDIT-OMS [Advantages of ordinal alpha over Cronbach's alpha illustrated with the AUDIT-OMS survey]. Pan American Journal of Public Health, (42), 1-6.

Darling, N. (1999). Parenting style and its correlates. ERIC Digest, ED427896.

Retrieved

http://files.eric.ed.gov/fulltext/ED427896.pdf

Darling, N., \& Steinberg, L. (1993). Parenting Style as Context: An Integrative Model. Psychological Bulletin, 113(3), 487-496. https://doi.org/10.1037/0033-2909.113.3.487

Darling, N., \& Toyokawa, T. (1997). Construction and validation of the parenting style inventory II (PSI-II). Unpublished Manuscript.

Diaconu-Gherasim, L. R., \& Măirean, C. (2016). Perception of parenting styles and academic achievement: The mediating role of goal orientations. Learning and Individual Differences, 49, 378-385. https://doi.org/10.1016/j.lindif.2016.06.026

Dunn, T. J., Baguley, T., \& Brunsden, V. (2014). From alpha to omega: A practical solution to the pervasive problem of internal consistency estimation. British Journal of Psychology, 105(3), 399-412. https://doi.org/10.1111/bjop.12046

Ey, S., Hadley, W., Allen, D. N., Palmer, S., Klosky, J., Deptula, D., ... Cohen, R. (2005). A new measure of children's optimism and pessimism: The youth life orientation test. Journal of Child Psychology and Psychiatry and Allied Disciplines, 46(5), 548-558. https://doi.org/10.1111/j.1469-7610.2004.00372.x

Ferrando, P. J., \& Lorenzo-Seva, U. (2014). Exploratory Item Factor Analysis: some additional considerations. Anales de Psicología, 30(3), 1170-1175. https://doi.org/10.6018/analesps.30.3.199991

Fornell, C., \& Larcker, D. (1981). Evaluating Structural Equation Models with Unobservable Variables and Measurement Error: A Comment. Journal of Marketing Research, 18, 39-50. https://doi.org/10.2307/3150979

Fuentes, M. C., García, F., Gracia, E., \& Alarcón, A. (2015). Los estilos parentales de socialización y el ajuste psicológico. Un estudio con adolescentes españoles [Parental styles of socialization and psychological adjustment. A study with Spanish adolescents]. Revista de Psicodidáctica, 20(1), 117-138.

García, F., Serra, E., García, O. F., Martínez, I., \& Cruise, E. (2019). A Third Emerging Stage for the Current Digital Society? Optimal Parenting Styles in Spain, the United States, Germany, and Brazil. International Journal of Environmental Research and Public Health, 16(13), 2333. https://doi.org/10.3390/ijerph16132333

Gerard, A. B. (1994). Parent-child relationship inventory (PCRI). Los Ángeles, LA: Western psychological services. Retrieved from https://vpsyche.com/course/parent-child-relationship-inventory-pcri/
Glorfeld, L. (1995). An Improvement on Horn's Parallel Analysis Methodology for Selecting the Correct Number of Factors to Retain. Educational and Psychological Measurement, 55(3), 377-393.

Gonzáles, N. A., Cauce, A. M., \& Mason, C. A. (1996). Interobserver agreement in the assessment of parental behavior and parentadolescent conflict: African American mothers, daughters, and independent observers. Child Development, 67(4), 1483-1498.

González-Cámara, M., Osorio, A., \& Reparaz, C. (2019). Measurement and Function of the Control Dimension in Parenting Styles: A Systematic Review. International Journal of Environmental Research and Public Health, 16(17), 3157. Retrieved from https://www.mdpi.com/1660$4601 / 16 / 17 / 3157 / \mathrm{pdf}$

Gustems-Carnicer, J., Calderón, C., \& Forn Santacana, M. (2017) Psychometric properties of the Life Orientation Test (LOT-R) and its relationship with psychological well-being and academic progress in college students. Revista Latinoamericana de Psicologia, 49(1), 19-27. https://doi.org/10.1016/j.rlp.2016.05.001

Hasan, N., \& Power, T. G. (2002). Optimism and pessimism in children: A study of parenting correlates. International Journal of Behavioral Development, 26(2), https://doi.org/10.1080/01650250114300003

Hinz, A., Sander, C., Glaesmer, H., Brähler, E., Zenger, M., Hilbert, A., \& Kocalevent, R. D. (2017). Optimism and pessimism in the general population: Psychometric properties of the Life Orientation Test (LOT-R). International Journal of Clinical and Health Psychology, 17(2), 161170. https://doi.org/10.1016/j.ijchp.2017.02.003

Hu, L. T., \& Bentler, P. (1999). Cutoff Criteria for Fit Indexes in Covariance Structure Analysis: Conventional Criteria Versus New Alternatives, Structural Equation Modeling. Structural Equation Modeling, 6(1), 1-55. https://doi.org/http://dx.doi.org/10.1080/10705519909540118

Kapikiran, Ş., \& Acun-Kapikiran, N. (2016). Optimism and Psychological Resilience in Relation to Depressive Symptoms in University Students: Examining the Mediating Role of Self-Esteem. Educational Sciences: Theory and Practice, 16(6), 2087-2110.

Laird, R. D., \& Zeringue, M. M. (2019). Parental knowledge and child disclosure as they relate to prosocial and antisocial behaviors. In The Oxford Handbook of Parenting and Moral Development (pp. 319-338). Oxford University Press.

Laursen, B., \& Collins, W. A. (2009). Parent-child relationships during adolescence. In R. M. Lerner \& L. Steinberg (Eds.), Handbook of adolescent psychology (3rd ed., Vol. 2). Hoboken, NJ: Wiley Online Library. Retrieved from https://pdfs.semanticscholar.org/f329/d6be24f5d38b6eb6eeebddb8d1 70775 fedf9.pdf

Lloret-Segura, S., Ferreres-Traver, A., Hernández-Baeza, A., \& TomásMarco, I. (2014). (2014). El análisis factorial exploratorio de los ítems : una guía práctica, revisada y actualizada [The exploratory factor analysis of the items: a practical guide, revised and updated]. Introducción Determinación de la adecuación del Análisis, 30, 1151-1169.

Maccoby, E. E., \& Martin, J. A. (1983). Socialization in the contex of the family: Parent-child interaction. In P. H. Mussen \& E. M. Hetherington (Eds.), Handbook of Child Psychology. Socialization, personality, and social development, Vol 4 (4th ed., pp. 1-101). New York, NY: New York: Wiley.

Mageau, G. A., Ranger, F., Joussemet, M., Koestner, R., Moreau, E., \& Forest, J. (2015). Validation of the Perceived Parental Autonomy Support Scale (P-PASS). Canadian Journal of Behavioural Science/Revue Canadienne Des Sciences Du Comportement, 47(3), 251. https://doi.org/http://dx.doi.org/10.1037/a0039325

Mounts, N. S., \& Allen, C. (2019). Parenting Styles and Practices. In D. J. Laible, G. Carlo, \& L. M. Padilla-Walker (Eds.), The Oxford Handbook of Parenting and Moral Development (pp. 41-56). New York, NY: Oxford University Press.

Muñiz, J., \& Fonseca-Pedrero, E. (2019). Ten steps for test development. Psicothema, 31 (1), 7-16. DOI: 10.7334/psicothema2018.291.

Musitu, G., \& García, F. (2001). Escala de socialización parental en la adolescencia (ESPA29)[Parental socialization scale in adolescence (ESPA29)]. Madrid: TEA ediciones. 
O’Rourke, N., \& Hatcher, L. (2013). A Step-by-Step Approach to Using SAS ® for Factor Analysis and Structural Equation Modelling, Second Edition. SAS Institute Inc. (Second Edi). Cary, NC.

Oliva, A., Antolín, L., Pertegal, M. Á., Ríos, M., Parra, Á., Hernando, Á., \& Reina, M. del C. (2011). Instrumentos para la evaluación de la salud mental y el desarrollo Positivo adolescente y los activos que lo promueven [Instruments for the evaluation of mental health and positive adolescent development and the assets that promote it]. (Junta de A, Vol. 6).

Oliva, A., Parra, Á., Sánchez-Queija, I., \& López, F. (2007). Estilos educativos materno y paterno: Evaluación y relación con el ajuste adolescente [Maternal and paternal educational styles: Evaluation and relationship with adolescent adjustment]. Anales de Psicología, 23(1), 4956.

Ortega, M. E., \& Triana, B. (2002). Cuestionario de Clima Familiar [Family Climate Questionnaire]. Versión Subsistema Paterno-Filial. Modelo Para Adolescentes. Documento No Publicado. Universidad de La Laguna.

Osorio, A., \& González-Cámara, M. (2016). Testing the alleged superiority of the indulgent parenting style among Spanish adolescents. Psicothema, 28(4), 414-420. from http://www.psicothema.es/pdf/4344.pdf

Pasquali, L., \& de Araújo, J. M. A. (1986). Questionário de percepção dos pais-QPP. Psicologia: Teoria e Pesquisa, 2(1), 56-72. Retrieved from periodicos.unb.br/index.php/revistaptp/article/download/16989/154 75

Pearce, L. D., Hayward, G. M., Chassin, L., \& Curran, P. J. (2018). The Increasing Diversity and Complexity of Family Structures for Adolescents. Journal of Research on Adolescence, 28(3), 591-608. https://doi.org/10.1111/jora.12391

Pinquart, M. (2016). Associations of Parenting Styles and Dimensions with Academic Achievement in Children and Adolescents: A Meta-analysis. Educational Psychology Review, 28(3), 475-493. https://doi.org/10.1007/s10648-015-9338-y

Rohner, R. P., \& Khaleque, A. (2005). Parental acceptance-rejection questionnaire (PARQ): Test manual. Handbook for the Study of Parental Acceptance and Rejection, 4, 43-106.

Royo, F. (2016). Optimismo, rendimiento académico y adaptación escolar [Optimism, academic performance and school adaptation?. Doctoral dissertation: Universidad de Zaragoza.

SAS. (2020). SAS Product Support $A$ to $Z$. Retrieved from https://support.sas.com/en/software/all-products-support.html

Schaefer, E. S. (1965). A configurational analysis of children's reports of parent behavior. Journal of Consulting Psychology, 29(6), 552.

Scheier, M. F., Carver, C. S., \& Bridges, M. W. (1994). Distinguishing optimism from neuroticism (and trait anxiety, self-mastery, and self- esteem): a reevaluation of the Life Orientation Test. Journal of Personality and Social Psychology, 67(6), 1063-1078. Retrieved from https://doi.org/10.1037/0022-3514.67.6.1063

Shelton, K. K., Frick, P. J., \& Wootton, J. (1996). Assessment of parenting practices in families of elementary school-age children. Journal of Clinical Child Psychology, 25(3), 317-329. Retrieved from https://sites01.lsu.edu/faculty/pfricklab/wp-

content/uploads/sites/100/2015/11/Clinical-Child-Psych.-1996. Parenting-Practices.pdf

Smetana, J. G. (2017, June 1). Current research on parenting styles, dimensions, and beliefs. Current Opinion in Psychology. Elsevier B.V. https://doi.org/10.1016/j.copsyc.2017.02.012

Stattin, H., \& Kerr, M. (2000). Parental monitoring: A reinterpretation. Child Development, 71(4), 1072-1085.

Steinberg, L. (2001). We know some things: Parent-adolescent relationships in retrospect and prospect. Journal of Research on Adolescence, 11(1), 1-19. Retrieved from https://onlinelibrary.wiley.com/doi/pdf/10.1111/1532-7795.00001

Steinberg, L., Lamborn, S. D., Dornbusch, S. M., \& Darling, N. (1992). Impact of parenting practices on adolescent achievement: Authoritative parenting, school involvement, and encouragement to succeed. Child Development, 63(5), 1266-1281. Retrieved from https://www.jstor.org/stable/1131532

Steinberg, L., \& Silk, J. S. (2002). Parenting adolescents. In M. H. Bornstein (Ed.), Handbook of parenting (Vol. 1, pp. 103-133). Mahwah, NJ: Lawrence Erlbaum.

Varela, S. P., Bernal, A., \& Rivas, S. (2019). Early Childhood Development and Education: Theoretical Convergences and Divergences. International Education Studies, 12(7), 1-9. https://doi.org/10.5539/ies.v12n7p1

Waterman, E. A., \& Lefkowitz, E. S. (2017). Are Mothers' and Fathers' Parenting Characteristics Associated With Emerging Adults' Academic Engagement? Journal of Family Issues, 38(9), 1239-1261. https://doi.org/10.1177/0192513X16637101

Zacarías-Salinas, X., \& Andrade-Palos, P. (2014). Una escala para evaluar prácticas parentales que promueven la conducta prosocial en preadolescentes [A scale for evaluating parenting practices that promote prosocial behavior in preadolescents]. Revista Iberoamericana de Diagnóstico y Evaluación-e Avaliação Psicológica, 2(38), 117-135. Retrieved from https://www.redalyc.org/pdf/4596/459645434007.pdf

Zumbo, B. D., Gadermann, A. M., \& Zeisser, C. (2007). Ordinal Versions of Coefficients Alpha and Theta for Likert Rating Scales. Journal of Modern Applied Statistical Methods, 6(1), 21-29. 